\title{
The Mediating Role of Visual Stimuli From Media Use at Bedtime on Psychological Distress and Fatigue in College Students: Cross-Sectional Study
}

\author{
Yuan Guan ${ }^{1}, \mathrm{PhD}$; Wenjie Duan ${ }^{2}, \mathrm{PhD}$ \\ ${ }^{1}$ Department of Social Work, Guangdong University of Finance, Guangzhou, China \\ ${ }^{2}$ Social and Public Administration School, East China University of Science and Technology, Shanghai, China
}

Corresponding Author:

Wenjie Duan, $\mathrm{PhD}$

Social and Public Administration School

East China University of Science and Technology

130 Meilong Road

Xuhui District

Shanghai

China

Phone: 8617269306934

Email: duan.w@outlook.com

\section{Abstract}

Background: Empirical research has linked psychological distress with fatigue. However, few studies have analyzed the factors (eg, stimuli from bedtime media use) that affect the relationship between psychological distress and fatigue.

Objective: The aim of this study was to examine whether visual stimuli from bedtime media use mediate the relationship between psychological distress and fatigue among college students.

Methods: The sample included 394 participants (92 males, 302 females) with a mean age of 19.98 years (SD 1.43 years), all of whom were Chinese college students at an occupational university in Sichuan Province, China. Data were collected using a paper-based questionnaire that addressed psychological distress, stimuli from bedtime media use, and fatigue. Mediation analysis was conducted using the PROCESS macro version 2.16.2 for SPSS 22, which provided the 95\% CIs.

Results: Both psychological distress $(\mathrm{r}=.43, P<.001)$ and visual stimuli from bedtime media use $(\mathrm{r}=.16, P<.001)$ were positively related to fatigue. The association between auditory stimuli from bedtime media use and fatigue was not significant ( $\mathrm{r}=.09, P=.08)$. The relationship between psychological distress and fatigue was partially mediated by visual stimuli from bedtime media use (beta=.01, SE 0.01, 95\% CI 0.0023-0.0253).

Conclusions: The findings imply that psychological distress has an indirect effect on fatigue via visual stimuli from bedtime media use. In contrast, auditory stimuli from bedtime media use did not have the same effect. We suggest that college students should reduce bedtime media use, and this could be achieved as part of an overall strategy to improve health. Mobile health apps could be an option to improving young students' health in daily life.

(JMIR Ment Health 2020;7(3):e11609) doi: 10.2196/11609

\section{KEYWORDS}

psychological distress; visual stimulus; auditory stimulus; bedtime media use; fatigue

\section{Introduction}

\section{Fatigue and Its Influence}

Fatigue is a subjective feeling of tiredness or a sustained sense of exhaustion $[1,2]$. It includes the experience of fatigue and the influence of fatigue on physical, mental, and social aspects of life $[1,2]$. Fatigue is common among students in China [3].
In a study of 757 Chinese adolescent students in Taiwan, Chen et al [4] found relatively high proportions of fatigue in grades 9 through 12 , primarily owing to the pressure students faced related to university entrance exams. Fatigue has a negative influence on students' school performance [5] and health [6]. For example, using data from 60 college-aged students, Palmer [7] found that fatigue had a negative influence on students' 
learning and cognitive performance. In their study of 109 medical students aged 21-40 years, Hwang et al [8] found that students with clinical fatigue had low scores for physical health and psychological health.

\section{Fatigue and Related Research}

Fatigue has attracted considerable research interest in recent years. The large proportions of students who experience fatigue and the serious consequences of fatigue highlight the need to explore the psychological mechanisms that underlie fatigue. Although most of the published studies have attempted to estimate the negative consequence of fatigue, relatively few studies have analyzed the factors influencing fatigue. Some research has focused on the risk factors for fatigue, such as daily activities [9] and daily events [10]. However, only a few studies have investigated the factors influencing fatigue, such as bedtime media use. Using data from 358 university students, Zarghami et al [11] found that using a cell phone after switching off the main bedroom light was associated with fatigue. Also, relatively few studies have explored the relationship between psychological distress, an important influencing factor and intervening variable, and fatigue among college students in China.

\section{Psychological Distress and Fatigue}

Psychological distress is a composite concept that describes the negative symptoms of a person's mental health, such as depression, anxiety, or other emotional dysregulation $[12,13]$. Psychological distress is positively related to fatigue $[4,14,15]$. Based on one-way ANOVA analysis of data from a cross-sectional survey of 355 first-year rural college students, Hussain et al [16] found that fatigued students experienced higher levels of psychological distress. In a longitudinal study of 243 college students in South Korea, Shim et al [17] found that depression is positively associated with fatigue.

\section{Media Use and Psychological Distress}

Despite the association between psychological distress and fatigue, the mediating mechanism related to bedtime media use has not been explored. Research on media use has recently become a hot topic. Media use is prevalent among youth [18,19], especially at bedtime [20]. Psychological distress is related to media use [21-23] and positively influences media use [24,25]. For example, in their study with 923 college students in Jiangxi Province, China, Ye and Zheng [26] found that psychological distress resulted in higher media use. Wills et al [27] found that addictive forms of behavior were related with an inability of adolescents to control their emotions. Failure to control negative emotions leads to increased media use [28]. According to the social cognitive theory, self-regulation is a process in which people control their behaviors [29]. Failure to affective self-react (one of the processes of self-regulation) is associated with negative outcomes, such as addiction to media use [30].
Therefore, people who experience psychological distress tend to use media to comfort themselves and, especially at bedtime, to relieve psychological distress [31]. Meanwhile, according to the uses and gratifications theory [32,33], people achieve gratification when they meet their needs, and using specific types of media provided this gratification [33]. Psychological differences are one factor that drives individuals to gratify their needs $[24,33]$. Therefore, psychological distress is positively associated with media use [34].

\section{Media Use and Fatigue}

Many studies have shown that media use is related to fatigue [20,35-39], and frequent media use results in fatigue [40]. Bedtime media use leads to a later time to fall asleep and displaced sleeping times, which result in fatigue [20]. Moreover, bedtime media use results in irregular sleep [41], disrupting the endocrine system [42]. Students who use media at bedtime may experience two types of stimuli: visual and auditory. Bedtime media use increases the level of external stimuli (visual stimulus and auditory stimulus) at bedtime. Exposure to light at night influences the human biological clock [43,44], and visual stimuli at bedtime influence the neuroendocrine system [45], affecting sleep and resulting in fatigue the following day. Although stimulation at bedtime influences the neuroendocrine system and therefore fatigue [42], few studies have found an association between an auditory stimulus from bedtime media use and fatigue. However, there is limited evidence for an association between listening to music at bedtime and fatigue. With a sample of 844 adults (18-94 years old), Exelmans and Van den Bulck [20] found that listening to music before sleeping increases fatigue. The relationship between an auditory stimulus from bedtime media use and fatigue needs further research.

\section{Hypotheses}

In summary, psychological distress has a positive relationship with fatigue. Visual stimuli from bedtime media use have a potential mediating role between psychological distress and fatigue. This study aimed to explore the mediating effect of stimuli from bedtime media use on the relationship between psychological distress and fatigue among Chinese college students. First, we aimed to confirm the results of previous studies by testing the relationship between psychological distress and fatigue. Second, we aimed to extend the existing literature by examining the role of bedtime media use in the relationship between psychological distress and fatigue. We had two hypotheses: (1) psychological distress is positively correlated with fatigue, and (2) visual stimuli from bedtime media use mediate the positive correlation between psychological distress and fatigue. This paper not only provides new insight in this area but also provides practical methods to improve college students' health in China. The theory model is shown in Figure 1. 
Figure 1. Theory model of the mediating effect of a visual stimulus from bedtime media on the relationship between psychological distress and fatigue.

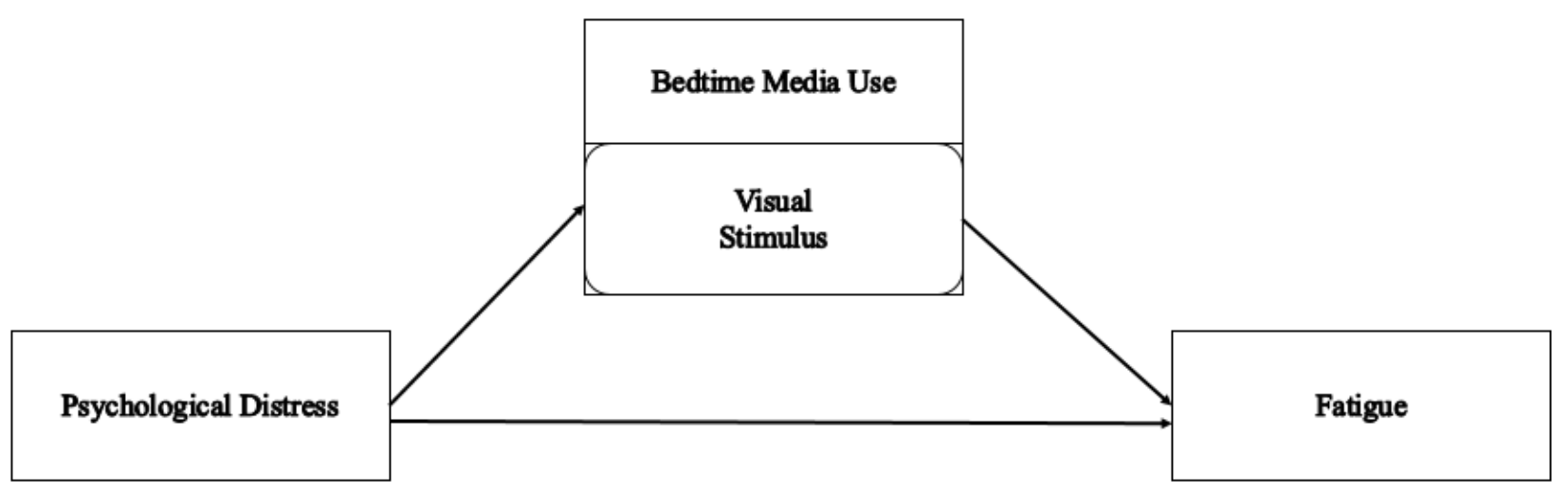

\section{Methods}

\section{Participants and Procedures}

A power analysis was conducted to estimate the minimum sample size using G Power software [46]. The regression model included 5 predictors (sex, age, psychological distress, visual stimulus, and auditory stimulus), the alpha was set at .05 , and the observed $\mathrm{R}^{2}$ in the regression model was 0.21 (Table 1). The minimum sample size was calculated at 158 participants. The power was 0.95 , which was an adequate value [47]. The participants were 468 freshmen from an occupational university in Sichuan Province, China. The inclusion criteria were age between 18 and 30 years old and owning a media device for daily use. All participants were asked to complete a questionnaire; $10.0 \%$ (47/468) of the participants refused to complete the questionnaire, and $6.4 \%$ (27/421) of the remaining participants did not complete the questionnaire. The data were collected in 2016, and 394 completed questionnaires were collected. All data were collected in the form of paper-based questionnaires. The flow chart of eligibility and participation is shown in Figure 2. A normal Q-Q plot and histogram showed that the fatigue scores were approximately normally distributed. The necessary ethical approval was obtained from the Human Research Ethics Committee of the Department of Sociology, Wuhan University, China, and the research was conducted in accordance with the Declaration of Helsinki. Written informed consent was obtained from all the participants.

Table 1. Results from the hierarchical regression analyses of the effects of the demographic variables, psychological distress, and stimuli from bedtime media use on the dependent variable, fatigue.

\begin{tabular}{|c|c|c|c|c|c|c|c|c|c|}
\hline & Step 1 & & & Step 2 & & & Step 3 & & \\
\hline & beta & $t$ & $P$ value & beta & $t$ & $P$ value & beta & $t$ & $P$ value \\
\hline Constant & 47.15 & 12.68 & $<.001$ & 46.70 & 13.80 & $<.001$ & 45.29 & 13.14 & $<.001$ \\
\hline Sex (male, female) & -1.61 & -2.57 & .01 & -1.14 & -1.99 & .047 & -1.46 & -2.50 & .01 \\
\hline Age (years) & 0.29 & 1.56 & .12 & 0.12 & 0.69 & .49 & 0.09 & 0.54 & .59 \\
\hline Psychological distress & & & & 0.25 & 9.04 & $<.001$ & 0.24 & 8.65 & $<.001$ \\
\hline Visual stimuli & & & & & & & 0.92 & 2.59 & .01 \\
\hline Auditory stimuli & & & & & & & -0.18 & -0.64 & .52 \\
\hline$R^{2}$ & .02 & & & .19 & & & .21 & & \\
\hline$F$ statistic & $F_{(2,391)}=4.34$ & & & $F_{(3,390)}=30.76$ & & & $F_{(5,388)}=20.27$ & & \\
\hline$P$ value & .01 & & & $<.001$ & & & $<.001$ & & \\
\hline
\end{tabular}


Figure 2. Flow chart of eligibility and participation.

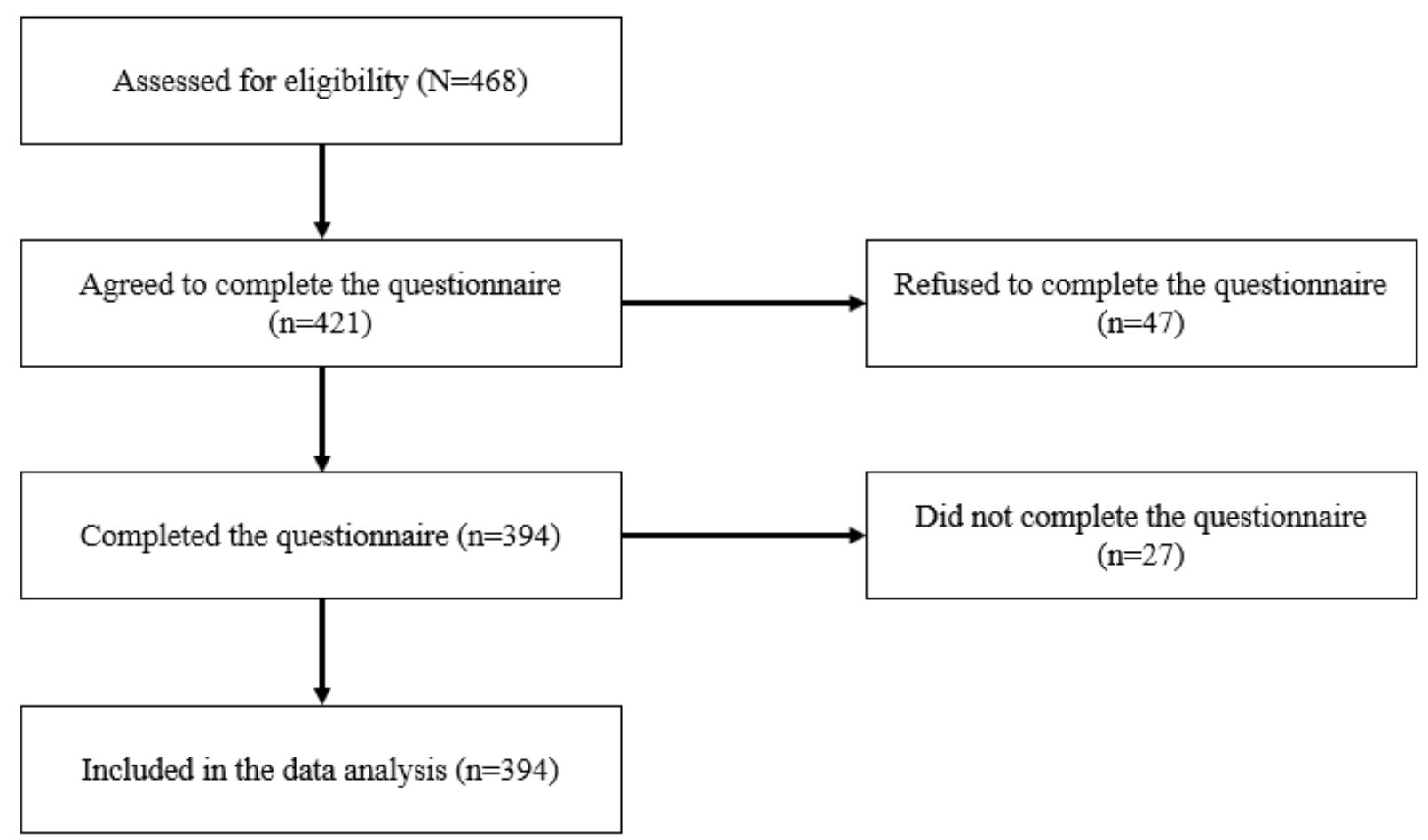

\section{Measures}

\section{Psychological Distress}

The Depression Anxiety Stress Scales (DASS) can be used to measure general psychological distress [48]. As a self-reported instrument, the DASS measures the three related psychological states of depression, anxiety, and stress [49]. It is a 4-point scale that asks participants about their experiences in the past week (eg, "I felt that life was meaningless"), with scores ranging from 0 ("This item does not apply to me at all.") to 3 ("This item applies to me very much."). No item is reverse-coded. The short version, DASS-21, has half the questions of the DASS-42 and is suitable for research use rather than clinical use [50]. The total score of the DASS-21 provides a composite/general measure of the negative psychological distress of the general population rather than for people with a specific psychological state [50]. Therefore, the DASS-21 was suitable for this exploratory study, which did not measure the endocrine index as is done in a biomedical experiment. Research has shown that the psychometric properties of the Chinese version of the DASS-21 is acceptable [51]. The Cronbach alpha of the current sample was .89. The total score of the DASS-21 was used to measure psychological distress among college students.

\section{Bedtime Media Use}

Based on previous studies [20,38,39,52,53], we asked the respondents how often they used media to help them fall asleep (eg, surfed the internet or watched videos) and about the two types of stimuli (ie, auditory stimulus and visual stimulus) before bedtime. Visual stimuli included playing computer games, watching videos, or surfing the internet on a computer; playing computer games, watching videos, or sending short messages on a smartphone; and reading. Auditory stimuli included listening to music and making phone calls. For example, we asked how often the respondent played computer games to help them fall asleep, with responses on a 6-point scale, from $1=$ never to $6=$ always. For the statistical analyses, the mean scores of the 7 visual stimulation activities and the mean scores of the 2 auditory stimulation activities were calculated.

\section{Fatigue}

The PROMIS Fatigue Short-Form 7a measures self-reported fatigue using a single total score [1]. The 7 questions (eg, "How often did you experience extreme exhaustion in the past seven days?") each have a possible score from 1 (never) to 5 (always). The Fatigue Short-Form 7a scale is available to use with college students (age $\geq 18$ years), and the Chinese version is available from PROMIS [54]. The psychometric properties of the PROMIS scale have been tested [55]. The Cronbach alpha of fatigue was .78. For the statistical analyses, the total score of the 7 items was transformed to a standardized T score (mean 50 points, SD 10 points) using the coding from PROMIS [54]. As a self-reported instrument, the PROMIS Fatigue Short-Form $7 \mathrm{a}$ is available to assess fatigue for people without a clinical condition such as general-population university students.

\section{Data Analysis}

The pairwise method was used to handle missing data. First, descriptive statistics and the correlation matrix were calculated. We expected that psychological distress, stimuli from bedtime media use, and fatigue would be positively related to each other. Second, hierarchical regressions were performed using the entry method to explore the roles of psychological distress and stimuli from bedtime media use on fatigue. In the hierarchical regression, fatigue acted as the dependent variable. Demographic variables (ie, age and sex, coded as 1 for male and 0 for female) were entered in step 1 , followed by psychological distress in 
step 2. The two types of stimuli from bedtime media use were entered in step 3. Third, using the results from the hierarchical regressions, the mediating effect was examined using the PROCESS macro version 2.16.2 for SPSS 20.0 (IBM Corp, Armonk, NY) [56]. Bootstrapping was set at 5000 resamples to provide robust estimates of the $95 \%$ CIs of the standardized effects [57]. We examined if the stimuli from bedtime media use mediated the association between psychological distress and fatigue. A model was constructed with psychological distress as the predictor $(\mathrm{X})$, fatigue as the outcome $(\mathrm{Y})$, and visual stimulus from bedtime media use as the mediator (M). Covariates included sex and age. Our model describes path a as the direct effect of the psychological distress regressed on the visual stimuli from bedtime media use. Path $b$ is the direct effect of visual stimuli from bedtime media use regressed on fatigue. Path $\mathrm{c}$ is the direct effect of psychological distress regressed on fatigue. Path c' is the mediating effect of psychological distress regressed on fatigue through visual stimuli from bedtime media use $\left(\mathrm{c}^{\prime}=\mathrm{a} * \mathrm{~b}\right) . P$ values are two-tailed, and the statistical significance level was set at $P<.05$.

\section{Results}

\section{Sample Characteristics}

The mean age was 19.98 years (SD 1.43 years, range 18-26 years), and 76.6\% (302/394) of the participants were female.

\section{Bivariate Correlation Analyses}

The mean (SD) points for visual stimuli from bedtime media use, the auditory stimuli from bedtime media use, psychological distress, and fatigue were 3.08 points ( 0.84 points), 3.76 points (1.04 points), 15.19 points ( 8.89 points), and 52.55 points (5.32 points), respectively. Visual and auditory stimuli from bedtime media use had a significant positive relationship $(\mathrm{r}=.56, P<.001)$. Psychological distress had a significant positive relationship with fatigue ( $\mathrm{r}=.43, P<.001)$. Psychological distress also had a significant positive relationship with visual stimuli from bedtime media use $(\mathrm{r}=.13, P=.009)$, while the relationship between psychological distress and auditory stimuli from bedtime media use was not significant $(\mathrm{r}=.10, P=.059)$. Visual stimuli from bedtime media use had a significant positive relationship with fatigue ( $r=.16, P<.001)$, while the relationship between auditory stimuli from bedtime media use and fatigue was not significant $(\mathrm{r}=.09, P=.08)$. Therefore, the effect of visual and auditory stimuli from bedtime media use on psychological distress might differ. And, the two types of stimuli from bedtime media use might have different effects on fatigue.

\section{Hierarchical Regression Analyses}

The results of the hierarchical regression analyses are shown in Table 1. All regression equations were statistically significant $\left(F_{(2,391)}>4.34, P<.05\right)$. Psychological distress was positively related to fatigue $\left(\mathrm{t}_{390}=9.04, P<.001\right)$. The two types of stimuli from bedtime media use were entered in step 3 , and the results showed that visual stimuli had a small yet significant explained variance on fatigue $\left(\mathrm{t}_{388}=2.59, P=.01\right)$. The effect of auditory stimuli regressed on fatigue was not significant $\left(\mathrm{t}_{388}=-.64\right.$, $P=.52$ ). These results support hypothesis 1 , that psychological distress and visual stimuli from bedtime media use positively affected fatigue.

\section{Analyses of Mediating Factors}

The results of the analyses of the mediating effects of stimuli from bedtime media use are shown in Table 2. As shown in Figure 3, psychological distress was significantly related to visual stimuli from bedtime media use (path a: beta=.01, SE $0.005, P=.006)$. Bedtime media use was significantly correlated with fatigue (path $\mathrm{b}$ : beta=.79, SE 0.29, $P=.007$ ).

Based on the bivariate analysis, psychological distress was correlated with fatigue (path c: beta $=.24$, SE $0.03, P<.001$ ) when controlling for visual stimuli from bedtime media use. Consistent with hypothesis 3 , there was an indirect effect of psychological distress on fatigue through the visual stimuli from bedtime media use (path c': beta=.01, bootstrapped SE 0.01, bootstrapped 95\% CI 0.0023-0.0253). Therefore, the positive association between psychological distress and fatigue was partially mediated by visual stimuli from bedtime media use.

Table 2. Mediating effect of the visual stimuli from bedtime media use on the relationship between psychological distress and fatigue.

\begin{tabular}{|c|c|c|c|c|c|}
\hline Path & $R^{2}$ & beta & SE & $P$ value & $95 \% \mathrm{CI}$ \\
\hline Psychological distress and visual stimuli & .05 & .01 & 0.01 & .006 & $0.0039-0.0225$ \\
\hline Visual stimuli and fatigue & .21 & .79 & 0.29 & .007 & $0.2152-1.3622$ \\
\hline Psychological distress and fatigue (direct effect) & & .24 & 0.03 & $<.001$ & $0.1842-0.2926$ \\
\hline Psychological distress and visual stimuli and fatigue (indirect effect) & & .01 & 0.01 & & $0.0023-0.0253$ \\
\hline
\end{tabular}


Figure 3. Direct effects (paths a, b, and c) of psychological distress and visual stimuli from bedtime media use on fatigue and an indirect effect (path c') of psychological distress on fatigue through the visual stimuli from bedtime media use. The control variables were age and sex.

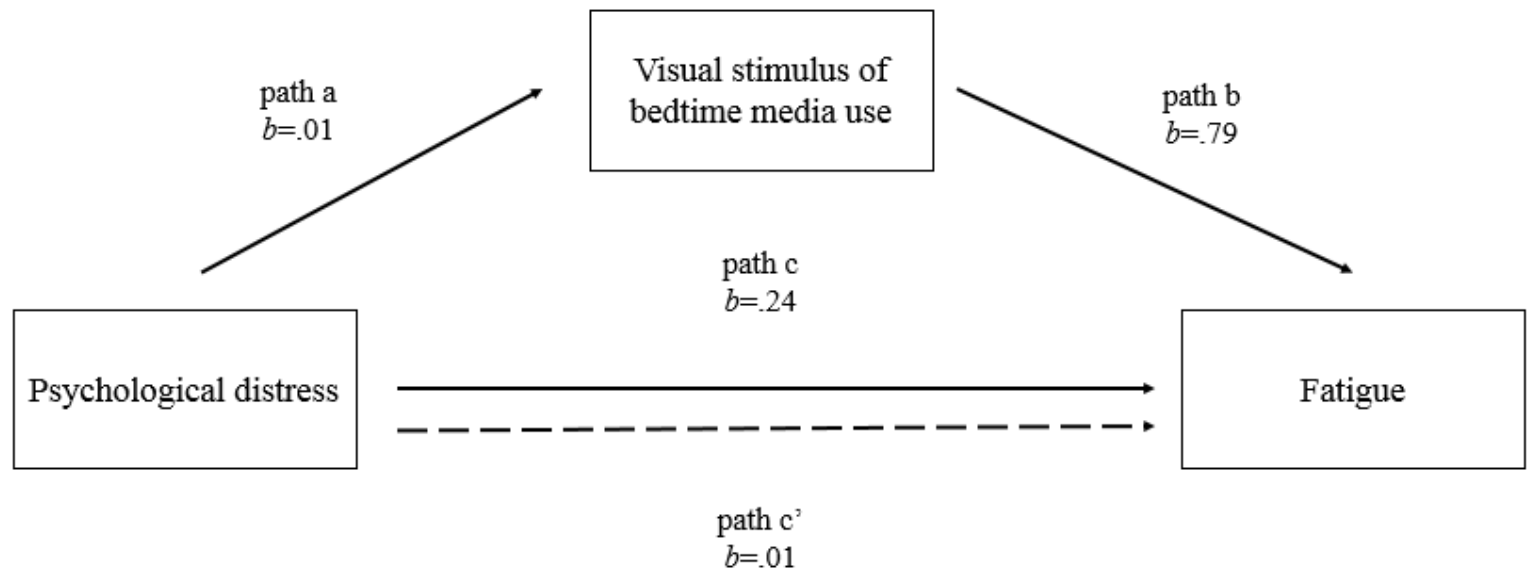

\section{Discussion}

\section{Study Objective}

To improve college students' health and ability to study efficiently, fatigue should not be neglected, especially when fatigue is associated with psychological health. This study explored the association between psychological distress and fatigue. The mediating mechanism of bedtime media use was also analyzed.

\section{Discussion of Findings Regarding the Hypotheses}

In line with our first hypothesis, there was a significant positive association between psychological distress and fatigue, which is consistent with results from previous studies [58-60]. It is conceivable that increasing psychological wellbeing and maintaining a good mood positively affect physiological systems and improve college students' vitality. Psychological interventions may help students maintain mental and physical health and increase their learning efficiency [61].

Supporting our second hypothesis, the association between psychological distress and fatigue was mediated by visual stimuli from bedtime media use. Due to the pressure from learning activities, it is common for young students to have mental health concerns [62]. Media use is a common method to regulate emotion [63]. Students with psychological distress increase their media use as a method for emotional regulation. This makes them feel comfortable and gratified [64]. However, visual stimuli from bedtime media use influence the endocrine system, disrupt the biological clock, and replace sleeping time. This potentially influences fatigue during the day. Students' schedules are restricted by school hours. Students who fall asleep later at night because of media use at bedtime may not compensate by getting up later and therefore not get enough sleep. This results in fatigue the next day. In this study, the relationship between auditory stimuli from bedtime media use and fatigue was not significant. Therefore, the effect of an auditory stimulus from bedtime media use might not be enough to disrupt sleep and cause fatigue among college students.

This paper provides practical strategies to improve the health of college students. First, administrators should consider the negative effect of stimuli from bedtime media use and provide students with an intervention to control bedtime media use. Equally important is students' awareness of ways to promote mental health. Educators who work to improve students' emotion regulatory abilities could teach skills to relieve psychological distress and address habitual excessive bedtime media use, such as through the practice of mindfulness [65]. This would help students improve their sleep quality [66] and decrease fatigue. Second, to reduce fatigue and improve study efficiency among college students, reducing bedtime media use, particularly the use of a smartphone screen, could be a good strategy to relieve psychological distress. Mobile health apps could be a good option to improve college students' health and working efficiency. Some mindfulness training apps, such as Headspace, provide courses to improve health through auditory resources only. App-based mindfulness training positively affects emotional regulation and sleep [67]. It could be a suitable option for college students to improve their health and avoid additional visual stimuli at bedtime.

\section{Limitations and Implications for Future Research}

Several limitations of this study should be noted. First, the sex distribution and generalizability need to be considered. Further data are needed to extend the results to students outside of China. Future research should improve the representativeness of the sample. Second, the items to measure media use and the content of media use need improvement, and further 
investigation is required. Although there were 7 items to measure visual stimuli from bedtime media use, there were only 2 items to measure auditory stimuli from bedtime media use. This might affect the validity of the results. As a result, future studies should improve the sample and measurements. Third, parents are an important influence on college students' daily behavior and mental health. Future research should consider controlling the effects of parental education level and occupation.

\section{Conclusions}

This paper contributes and expands the current research about the effects of stimuli from bedtime media use and psychological distress on fatigue among Chinese college students. Specifically, the results suggest that visual stimuli from bedtime media use can serve as a mediating factor to understand the association between psychological distress and fatigue. Further research should investigate the effects of the type (ie, playing games and social communication) of bedtime media use on mental and physical health.

\section{Acknowledgments}

The authors disclose receipt of the following financial support for the research, authorship, and/or publication of this article: "Application of Strength-Based Intervention in Multiple Groups," a research supporting project for high-level talent at East China University of Science and Technology (PI: Wenjie Duan).

\section{Conflicts of Interest}

None declared.

\section{References}

1. Lai J, Cella D, Choi S, Junghaenel DU, Christodoulou C, Gershon R, et al. How item banks and their application can influence measurement practice in rehabilitation medicine: a PROMIS fatigue item bank example. Arch Phys Med Rehabil 2011 Oct;92(10 Suppl):S20-S27 [FREE Full text] [doi: 10.1016/j.apmr.2010.08.033] [Medline: 21958919]

2. PROMIS. HealthMeasures. 2019. PROMIS Fatigue Scoring Manual URL: http://www.healthmeasures.net/images/PROMIS/ manuals/PROMIS Fatigue Scoring_Manual.pdf [accessed 2020-01-16]

3. Kang J, Chen S. Effects of an irregular bedtime schedule on sleep quality, daytime sleepiness, and fatigue among university students in Taiwan. BMC Public Health 2009 Jul 19;9:248 [FREE Full text] [doi: 10.1186/1471-2458-9-248] [Medline: 19615098]

4. Mao W, Chen T, Chou Y, Tzeng N, Chang H, Kuo S, et al. Effects of a selective educational system on fatigue, sleep problems, daytime sleepiness, and depression among senior high school adolescents in Taiwan. NDT 2015 Mar:741. [doi: 10.2147/ndt.s77179]

5. Matos MG, Gaspar T, Tomé G, Paiva T. Sleep variability and fatigue in adolescents: Associations with school-related features. Int J Psychol 2016 Oct;51(5):323-331. [doi: 10.1002/ijop.12167] [Medline: 25940538]

6. Pozos-Radillo E, Preciado-Serrano L, Plascencia-Campos A, Valdez-López R, Morales-Fernández A. Psychophysiological Manifestations Associated With Stress in Students of a Public University in Mexico. J Child Adolesc Psychiatr Nurs 2016 May;29(2):79-84. [doi: 10.1111/jcap.12142] [Medline: 27279437]

7. Palmer L. The Relationship between Stress, Fatigue, and Cognitive Functioning. College Student Journal 2013;47(2):312-325.

8. Hwang IC, Park KH, Kim JJ, Yim J, Ko KP, Bae SM, et al. Perceived Social Support as a Determinant of Quality of Life Among Medical Students: 6-Month Follow-up Study. Acad Psychiatry 2017 Apr;41(2):180-184. [doi: 10.1007/s40596-016-0503-5] [Medline: 26902854]

9. Greene KM, Maggs JL. Academic time during college: Associations with mood, tiredness, and binge drinking across days and semesters. J Adolesc 2017 Apr;56:24-33 [FREE Full text] [doi: 10.1016/j.adolescence.2016.12.001] [Medline: 28130974]

10. Van Laethem M, Beckers DG, Dijksterhuis A, Geurts SA. Stress, fatigue, and sleep quality leading up to and following a stressful life event. Stress Health 2017 Oct 18;33(4):459-469. [doi: 10.1002/smi.2730] [Medline: 27860130]

11. Zarghami M, Khalilian A, Setareh J, Salehpour G. The Impact of Using Cell Phones After Light-Out on Sleep Quality, Headache, Tiredness, and Distractibility Among Students of a University in North of Iran. Iran J Psychiatry Behav Sci 2015 Dec 23;9(4):e2010 [FREE Full text] [doi: 10.17795/ijpbs-2010] [Medline: 26834802]

12. Veit CT, Ware JE. The structure of psychological distress and well-being in general populations. Journal of Consulting and Clinical Psychology 1983;51(5):730-742. [doi: 10.1037/0022-006X.51.5.730]

13. Ridner SH. Psychological distress: concept analysis. J Adv Nurs 2004 Mar;45(5):536-545. [doi: 10.1046/j.1365-2648.2003.02938.x ]

14. Nyer M, Mischoulon D, Alpert JE, Holt DJ, Brill CD, Yeung A, et al. College students with depressive symptoms with and without fatigue: Differences in functioning, suicidality, anxiety, and depressive severity. Ann Clin Psychiatry 2015 May;27(2):100-108 [FREE Full text] [Medline: 25954936]

15. Dhir A, Yossatorn Y, Kaur P, Chen S. Online social media fatigue and psychological wellbeing-A study of compulsive use, fear of missing out, fatigue, anxiety and depression. International Journal of Information Management 2018 Jun;40:141-152. [doi: 10.1016/j.ijinfomgt.2018.01.012] 
16. Hussain R, Guppy M, Robertson S, Temple E. Physical and mental health perspectives of first year undergraduate rural university students. BMC Public Health 2013 Sep 15;13(1):848 [FREE Full text] [doi: 10.1186/1471-2458-13-848] [Medline: 24034822]

17. Shim E, Noh H, Yoon J, Mun HS, Hahm B. A longitudinal analysis of the relationships among daytime dysfunction, fatigue, and depression in college students. J Am Coll Health 2019 Jan 13;67(1):51-58. [doi: 10.1080/07448481.2018.1462819] [Medline: 29652615]

18. Karacic S, Oreskovic S. Internet Addiction Through the Phase of Adolescence: A Questionnaire Study. JMIR Ment Health 2017 Apr 03;4(2):e11 [FREE Full text] [doi: 10.2196/mental.5537] [Medline: 28373154]

19. Thom R, Bickham D, Rich M. Internet Use, Depression, and Anxiety in a Healthy Adolescent Population: Prospective Cohort Study. JMIR Mental Health 2018;5(2). [doi: 10.2196/preprints.8471]

20. Exelmans L, Van den Bulck J. The Use of Media as a Sleep Aid in Adults. Behav Sleep Med 2016 Oct 14;14(2):121-133. [doi: 10.1080/15402002.2014.963582] [Medline: 25313639]

21. Augner C, Hacker GW. Associations between problematic mobile phone use and psychological parameters in young adults. Int J Public Health 2012 Apr 3;57(2):437-441. [doi: 10.1007/s00038-011-0234-z] [Medline: 21290162]

22. Tao S, Wu X, Zhang S, Tong S, Hao J, Tao F. Association of alcohol use with problematic mobile phone use and depressive symptoms among college students in Anhui, China. J Public Health 2016 Oct 20;25(1):103-112. [doi:

$10.1007 / \mathrm{s} 10389-016-0766-\mathrm{z}]$

23. Demirci K, Akgönül M, Akpinar A. Relationship of smartphone use severity with sleep quality, depression, and anxiety in university students. J Behav Addict 2015 Jun;4(2):85-92 [FREE Full text] [doi: 10.1556/2006.4.2015.010] [Medline: 26132913]

24. Elhai J, Tiamiyu M, Weeks J, Levine J, Picard K, Hall B. Depression and emotion regulation predict objective smartphone use measured over one week. Personality and Individual Differences 2018 Oct;133:21-28 [FREE Full text] [doi: 10.1016/j.paid.2017.04.051]

25. Beranuy M, Oberst U, Carbonell X, Chamarro A. Problematic Internet and mobile phone use and clinical symptoms in college students: The role of emotional intelligence. Computers in Human Behavior 2009 Sep;25(5):1182-1187 [FREE Full text] [doi: 10.1016/j.chb.2009.03.001]

26. Ye B, Zheng Q. The Effects of Stress on College Students' Internet Addiction. Journal of Psychological Science 2016;39(3):621-627. [doi: 10.16719/j.cnki.1671-6981.20160317]

27. Wills TA, Pokhrel P, Morehouse E, Fenster B. Behavioral and emotional regulation and adolescent substance use problems: a test of moderation effects in a dual-process model. Psychol Addict Behav 2011 Jun;25(2):279-292 [FREE Full text] [doi: 10.1037/a0022870] [Medline: 21443302]

28. Kun B, Demetrovics Z. Emotional intelligence and addictions: a systematic review. Subst Use Misuse 2010 Jun 04;45(7-8):1131-1160. [doi: 10.3109/10826080903567855] [Medline: 20441455]

29. Bandura A. Social cognitive theory of self-regulation. Organizational Behavior and Human Decision Processes 1991 Dec;50(2):248-287 [FREE Full text] [doi: 10.1016/0749-5978(91)90022-1]

30. van Deursen AJ, Bolle C, Hegner S, Kommers P. Modeling habitual and addictive smartphone behavior. Computers in Human Behavior 2015 Apr;45:411-420 [FREE Full text] [doi: 10.1016/j.chb.2014.12.039]

31. Kim J, Seo M, David P. Alleviating depression only to become problematic mobile phone users: Can face-to-face communication be the antidote? Computers in Human Behavior 2015 Oct;51:440-447 [FREE Full text] [doi: 10.1016/j.chb.2015.05.030]

32. Blumler J, Katz E. The Uses of Mass Communications: Current Perspectives on Gratifications Research. Beverly Hills, California: Sage; 1974.

33. Blumler JG. The Role of Theory in Uses and Gratifications Studies. Communication Research 2016 Jun 30;6(1):9-36. [doi: $10.1177 / 009365027900600102]$

34. Elhai J, Dvorak R, Levine J, Hall B. Problematic smartphone use: A conceptual overview and systematic review of relations with anxiety and depression psychopathology. J Affect Disord 2017 Jan 01;207:251-259 [FREE Full text] [doi: 10.1016/j.jad.2016.08.030] [Medline: 27736736]

35. Saling L, Haire M. Are you awake? Mobile phone use after lights out. Computers in Human Behavior 2016 Nov;64:932-937. [doi: $10.1016 /$ j.chb.2016.08.006]

36. Durusoy R, Hassoy H, Özkurt A, Karababa AO. Mobile phone use, school electromagnetic field levels and related symptoms: a cross-sectional survey among 2150 high school students in Izmir. Environ Health 2017 Jun 02;16(1):51 [FREE Full text] [doi: 10.1186/s12940-017-0257-x] [Medline: 28577556]

37. Van den Bulck J. Adolescent use of mobile phones for calling and for sending text messages after lights out: results from a prospective cohort study with a one-year follow-up. Sleep 2007 Sep;30(9):1220-1223 [FREE Full text] [doi: 10.1093/sleep/30.9.1220] [Medline: 17910394]

38. Eggermont S, Van den Bulck J. Nodding off or switching off? The use of popular media as a sleep aid in secondary-school children. J Paediatr Child Health 2006 Jul;42(7-8):428-433. [doi: 10.1111/j.1440-1754.2006.00892.x] [Medline: 16898880]

39. Exelmans L, Van den Bulck J. Bedtime mobile phone use and sleep in adults. Soc Sci Med 2016 Jan;148:93-101. [doi: 10.1016/j.socscimed.2015.11.037] [Medline: 26688552] 
40. Khan M. Adverse effects of excessive mobile phone use. Int J Occup Med Environ Health 2008;21(4):289-293. [doi: 10.2478/v10001-008-0028-6] [Medline: 19228576]

41. Kamibeppu K, Sugiura H. Impact of the mobile phone on junior high-school students' friendships in the Tokyo metropolitan area. Cyberpsychol Behav 2005 Apr;8(2):121-130. [doi: 10.1089/cpb.2005.8.121] [Medline: 15938651]

42. Riemann D, Spiegelhalder K, Feige B, Voderholzer U, Berger M, Perlis M, et al. The hyperarousal model of insomnia: a review of the concept and its evidence. Sleep Med Rev 2010 Feb;14(1):19-31. [doi: 10.1016/j.smrv.2009.04.002] [Medline: 19481481]

43. González MMC, Aston-Jones G. Circadian regulation of arousal: role of the noradrenergic locus coeruleus system and light exposure. Sleep 2006 Oct;29(10):1327-1336. [doi: 10.1093/sleep/29.10.1327] [Medline: 17068987]

44. Lucas RJ, Peirson SN, Berson DM, Brown TM, Cooper HM, Czeisler CA, et al. Measuring and using light in the melanopsin age. Trends Neurosci 2014 Jan;37(1):1-9 [FREE Full text] [doi: 10.1016/j.tins.2013.10.004] [Medline: 24287308]

45. Maierova L, Borisuit A, Scartezzini J, Jaeggi SM, Schmidt C, Münch M. Diurnal variations of hormonal secretion, alertness and cognition in extreme chronotypes under different lighting conditions. Sci Rep 2016 Sep 20;6(1):33591 [FREE Full text] [doi: 10.1038/srep33591] [Medline: 27646174]

46. Mitchell-Box K, Braun KL. Fathers' thoughts on breastfeeding and implications for a theory-based intervention. J Obstet Gynecol Neonatal Nurs 2012;41(6):E41-E50. [doi: 10.1111/j.1552-6909.2012.01399.x] [Medline: 22861175]

47. Cohen J. Things I have learned (so far). American Psychologist 1990;45(12):1304-1312. [doi: 10.1037/0003-066x.45.12.1304]

48. Henry JD, Crawford JR. The short-form version of the Depression Anxiety Stress Scales (DASS-21): construct validity and normative data in a large non-clinical sample. Br J Clin Psychol 2005 Jun;44(Pt 2):227-239. [doi: 10.1348/014466505X29657] [Medline: 16004657]

49. Lovibond SH, Lovibond PF. Manual for the Depression Anxiety and Stress Scales 2ed. Sydney: Psychological Foundation of Australia; 1995.

50. University of New South Wales. DASS FAQ (Frequently Asked Questions) URL: http://www2.psy.unsw.edu.au/dass/ DASSFAQ.htm\# 1. What does the DASS measure, and [accessed 2020-01-16]

51. Wang K, Shi H, Geng F, Zou L, Tan S, Wang Y, et al. Cross-cultural validation of the Depression Anxiety Stress Scale-21 in China. Psychol Assess 2016 Dec;28(5):e88-e100. [doi: 10.1037/pas0000207] [Medline: 26619091]

52. Van den Bulck J. Television viewing, computer game playing, and Internet use and self-reported time to bed and time out of bed in secondary-school children. Sleep 2004 Feb 01;27(1):101-104. [doi: 10.1093/sleep/27.1.101] [Medline: 14998244]

53. Lemola S, Perkinson-Gloor N, Brand S, Dewald-Kaufmann JF, Grob A. Adolescents' electronic media use at night, sleep disturbance, and depressive symptoms in the smartphone age. J Youth Adolesc 2015 Feb;44(2):405-418. [doi: 10.1007/s10964-014-0176-x] [Medline: 25204836]

54. HealthMeasures. 2017. PROMIS Available Translations URL: http://www.healthmeasures.net/explore-measurement-systems/ promis/intro-to-promis/available-translations/117-available-translations [accessed 2020-01-16]

55. Cook KF, Jensen SE, Schalet BD, Beaumont JL, Amtmann D, Czajkowski S, et al. PROMIS measures of pain, fatigue, negative affect, physical function, and social function demonstrated clinical validity across a range of chronic conditions. J Clin Epidemiol 2016 Dec;73:89-102 [FREE Full text] [doi: 10.1016/j.jclinepi.2015.08.038] [Medline: 26952842]

56. Hayes AF. Introduction to Mediation, Moderation, and Conditional Process Analysis: A Regression-based Approach. New York: Guilford Press; 2013.

57. Preacher KJ, Hayes AF. Asymptotic and resampling strategies for assessing and comparing indirect effects in multiple mediator models. Behavior Research Methods 2008 Aug;40(3):879-891. [doi: 10.3758/BRM.40.3.879]

58. Laberge L, Ledoux E, Auclair J, Thuilier C, Gaudreault M, Gaudreault M, et al. Risk factors for work-related fatigue in students with school-year employment. J Adolesc Health 2011 Mar;48(3):289-294 [FREE Full text] [doi: 10.1016/j.jadohealth.2010.07.003] [Medline: 21338901]

59. Kim JA, Kang SW. Relationship among Sleep Quality, Heart Rate Variability, Fatigue, Depression, and Anxiety in Adults. Korean J Adult Nurs 2017;29(1):87. [doi: 10.7475/kjan.2017.29.1.87]

60. ter Wolbeek M, van Doornen LJ, Kavelaars A, Tersteeg-Kamperman MD, Heijnen CJ. Fatigue, depressive symptoms, and anxiety from adolescence up to young adulthood: a longitudinal study. Brain Behav Immun 2011 Aug;25(6):1249-1255. [doi: 10.1016/j.bbi.2011.04.015] [Medline: 21549830]

61. Liu F, Zhou N, Cao H, Fang X, Deng L, Chen W, et al. Chinese college freshmen's mental health problems and their subsequent help-seeking behaviors: A cohort design (2005-2011). PLoS One 2017 Oct 17;12(10):e0185531 [FREE Full text] [doi: 10.1371/journal.pone.0185531] [Medline: 29040266]

62. Li J, Lau JTF, Mo PKH, Su X, Tang J, Qin Z, et al. Insomnia partially mediated the association between problematic Internet use and depression among secondary school students in China. J Behav Addict 2017 Dec 01;6(4):554-563 [FREE Full text] [doi: 10.1556/2006.6.2017.085] [Medline: 29280394]

63. Bartsch A, Viehoff R. The Use of Media Entertainment and Emotional Gratification. Procedia - Social and Behavioral Sciences 2010;5:2247-2255. [doi: 10.1016/j.sbspro.2010.07.444]

64. Stevens EM, Dillman Carpentier FR. Facing Our Feelings. Communication Research 2016 Jul 08;44(1):3-28. [doi: $10.1177 / 0093650215587358]$ 
65. Duan W. Mediation role of individual strengths in dispositional mindfulness and mental health. Personality and Individual Differences 2016 Sep;99:7-10. [doi: 10.1016/j.paid.2016.04.078]

66. Ong JC, Manber R, Segal Z, Xia Y, Shapiro S, Wyatt JK. A randomized controlled trial of mindfulness meditation for chronic insomnia. Sleep 2014 Sep 01;37(9):1553-1563 [FREE Full text] [doi: 10.5665/sleep.4010] [Medline: 25142566]

67. Creswell JD. Mindfulness Interventions. Annu Rev Psychol 2017 Jan 03;68(1):491-516. [doi: 10.1146/annurev-psych-042716-051139] [Medline: 27687118]

\section{Abbreviations}

DASS: Depression Anxiety Stress Scale

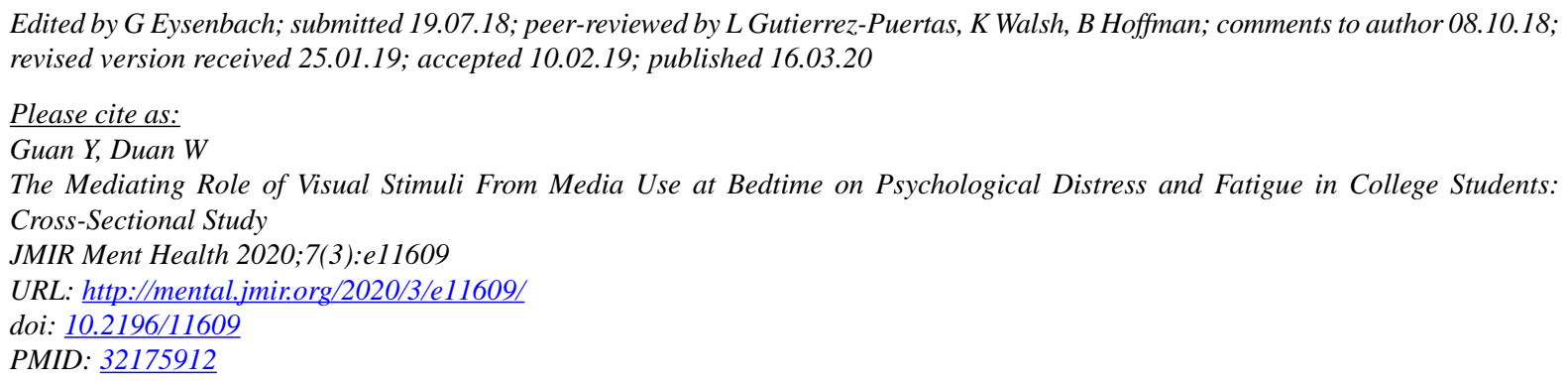

(C) Yuan Guan, Wenjie Duan. Originally published in JMIR Mental Health (http://mental.jmir.org), 16.03.2020. This is an open-access article distributed under the terms of the Creative Commons Attribution License (https://creativecommons.org/licenses/by/4.0/), which permits unrestricted use, distribution, and reproduction in any medium, provided the original work, first published in JMIR Mental Health, is properly cited. The complete bibliographic information, a link to the original publication on http://mental.jmir.org/, as well as this copyright and license information must be included. 